\title{
Front Matter: Volume 10187
}

, "Front Matter: Volume 10187," Proc. SPIE 10187, Anomaly Detection and Imaging with X-Rays (ADIX) II, 1018701 (28 June 2017); doi:

$10.1117 / 12.2281091$

SPIE. Event: SPIE Defense + Security, 2017, Anaheim, CA, United States 


\title{
PROCEEDINGS OF SPIE
}

\section{Anomaly Defection and Imaging with X-Rays (ADIX) II}

\author{
Amit Ashok \\ Edward D. Franco \\ Michael E. Gehm \\ Mark A. Neifeld \\ Editors
}

12-13 April 2017

Anaheim, California, United States

Sponsored and Published by

SPIE 
The papers in this volume were part of the technical conference cited on the cover and title page. Papers were selected and subject to review by the editors and conference program committee. Some conference presentations may not be available for publication. Additional papers and presentation recordings may be available online in the SPIE Digital Library at SPIEDigitalLibrary.org.

The papers reflect the work and thoughts of the authors and are published herein as submitted. The publisher is not responsible for the validity of the information or for any outcomes resulting from reliance thereon.

Please use the following format to cite material from these proceedings:

Author(s), "Title of Paper," in Anomaly Detection and Imaging with X-Rays (ADIX) II, edited by Amit Ashok, Edward D. Franco, Michael E. Gehm, Mark A. Neifeld, Proceedings of SPIE Vol. 10187 (SPIE, Bellingham, WA, 2017) Seven-digit Article CID Number.

ISSN: 0277-786X

ISSN: 1996-756X (electronic)

ISBN: 9781510608757

ISBN: 9781510608764 (electronic)

Published by

SPIE

P.O. Box 10, Bellingham, Washington 98227-0010 USA

Telephone +1 3606763290 (Pacific Time) · Fax +1 3606471445

SPIE.org

Copyright @ 2017 , Society of Photo-Optical Instrumentation Engineers.

Copying of material in this book for internal or personal use, or for the internal or personal use of specific clients, beyond the fair use provisions granted by the U.S. Copyright Law is authorized by SPIE subject to payment of copying fees. The Transactional Reporting Service base fee for this volume is $\$ 18.00$ per article (or portion thereof), which should be paid directly to the Copyright Clearance Center (CCC), 222 Rosewood Drive, Danvers, MA 01923. Payment may also be made electronically through CCC Online at copyright.com. Other copying for republication, resale, advertising or promotion, or any form of systematic or multiple reproduction of any material in this book is prohibited except with permission in writing from the publisher. The CCC fee code is 0277-786X/17/\$18.00.

Printed in the United States of America.

Publication of record for individual papers is online in the SPIE Digital Library.

\section{SPIE. DIGITAL \\ SPIEDigitalLibrary.org}

Paper Numbering: Proceedings of SPIE follow an e-First publication model. A unique citation identifier (CID) number is assigned to each article at the time of publication. Utilization of CIDs allows articles to be fully citable as soon as they are published online, and connects the same identifier to all online and print versions of the publication. SPIE uses a seven-digit CID article numbering system structured as follows:

- The first five digits correspond to the SPIE volume number.

- The last two digits indicate publication order within the volume using a Base 36 numbering system employing both numerals and letters. These two-number sets start with 00, 01, 02, 03, 04, 05, 06, 07, 08, 09, OA, OB ... 0Z, followed by 10-1Z, 20-2Z, etc. The CID Number appears on each page of the manuscript. 


\title{
Contents
}

\author{
$\checkmark$ Authors \\ vii Conference Committee
}

\section{SESSION 1 NOVEL SYSTEMS I}

1018706 Monte Carlo simulations of a novel coherent scatter materials discrimination system [10187-5]

\section{SESSION 2 NOVEL SYSTEMS II}

1018707 Sparse view Compton scatter tomography with energy resolved data: experimental and simulation results (Invited Paper) [10187-6]

1018708 Design and implementation of a fan beam coded aperture x-ray diffraction tomography system for checkpoint baggage scanning (Invited Paper) [10187-7]

1018709 Creating an experimental testbed for information-theoretic analysis of architectures for $\mathrm{x}$-ray anomaly detection [10187-8]

\section{SESSION 3 RECONSTRUCTION AND THREAT DETECTION ALGORITHMS I}

10187 OD Multi-energy penalized maximum-likelihood reconstruction for $x$-ray security imaging [10187-12]

10187 OE Representation-learning for anomaly detection in complex x-ray cargo imagery [10187-13]

10187 OF Image reconstruction for view-limited $x$-ray CT in baggage scanning [10187-14]

\section{SESSION $4 \quad$ X-RAY SOURCES AND DETECTORS}

10187 OG Towards brilliant, compact x-ray sources: a new x-ray photonic device (Invited Paper) [10187-15]

10187 Ol Multi-energy x-ray detectors to improve air-cargo security [10187-17]

10187 0J Impact of sub-pixelation within CdZnTe detectors for $\mathbf{x}$-ray diffraction imaging systems [10187-19] 
10187 OK Material-identification-free detection based on material-science-informed clustering [10187-20]

$10187 \mathrm{OL}$ A deep learning framework for the automated inspection of complex dual-energy $x$-ray cargo imagery [10187-21]

10187 OM Performance estimation for threat detection in CT systems (Invited Paper) [10187-23] 


\section{Authors}

Numbers in the index correspond to the last two digits of the seven-digit citation identifier (CID) article numbering system used in Proceedings of SPIE. The first five digits reflect the volume number. Base 36 numbering is employed for the last two digits and indicates the order of articles within the volume. Numbers start with 00, 01, 02, 03, 04, 05, 06, 07, 08, 09, OA, OB...0Z, followed by 10-1Z, 20-2Z, etc.

Andrews, Jerone T. A., OE

Ashok, Amit, 09, OF

Bilgin, Ali, OF

Bosch, Carl, OD

Castañón, David A., OM

Coccarelli, David, 09, OF

Couture, Aaron, 07

Denker, Jeff, 07

Desmal, Abdulla, 07

Edic, Peter, OG

Gehm, Michael E., 09, OF

Gong, Qian, 09

Greenberg, Joel A., 08, 09, OF, OK

Griffin, Lewis D., OE, OL

Hassan, Laila, 06

Hassan, Mehadi, 08

Hopkins, Forrest, OG

Huang, Liang-Chih, 09

Jaccard, Nicolas, OE, OL

Johnson, Eric, OD

Karl, W. Clem, OM

Lee, Susanne M., OG

LU, Jingwei, OD

MacDonald, C. A., 06

Mandal, Sudeep, $0 G$

Mandava, Sagar, 09, OF

Miller, Eric L., 07

Montémont, G., OJ

Montgomery, Trent, OM

Moulin, Vincent, 0 l

O'Sullivan, Joseph A., OD

Paulus, Caroline, $0 \mathrm{I}, \mathrm{JJ}$

Perion, Didier, 0 I

Petruccelli, Jonathan C., 06

Politte, David G., OD

Radisson, Patrick, 0 I

Regnerus, Brandon, 08

Rezaee, Hamideh, 07

Rogers, Thomas W., OE, OL

Salisbury, Joshua, OG

Scherer, Brian, OG

Schubert, Jeffrey R., 07

Starr-Baier, Sean, 06

Tabary, J., OJ

Tracey, Brian H., 07

Verger, Loïck, Ol, 0J

Wolter, Scott D., 08, OK

Yuan, Siyang, OK 
Proc. of SPIE Vol. 10187 1018701-6

Downloaded From: https://www.spiedigitallibrary.org/conference-proceedings-of-spie on 26 Apr 2023 Terms of Use: https://www.spiedigitallibrary.org/terms-of-use 


\title{
Conference Committee
}

\author{
Symposium Chair
}

Donald A. Reago Jr., U.S. Army Night Vision \& Electronic Sensors

Directorate (United States)

Symposium Co-chair

Arthur A. Morrish, Raytheon Space and Airborne Systems

(United States)

Conference Chairs

Amit Ashok, College of Optical Sciences, The University of Arizona (United States)

Edward D. Franco, Rapiscan Systems Laboratories (United States)

Michael E. Gehm, Duke University (United States)

Mark A. Neifeld, The University of Arizona (United States)

Conference Program Committee

Mark A. Anastasio, Washington University in St. Louis (United States)

George Barbastathis, Massachusetts Institute of Technology

(United States)

Ali Bilgin, The University of Arizona (United States)

Ali Can, GE Global Research (United States)

Eric W. Clarkson, The University of Arizona (United States)

Joel A. Greenberg, Duke University (United States)

Tim E. Harvey, EMF Corporation (United States)

Kris Iniewski, Redlen Technologies (Canada)

Robert R. Muise, Lockheed Martin Missiles and Fire Control (United States)

Joseph A. O'Sullivan, Washington University in St. Louis (United States)

Sondre Skatter, Safran Identity \& Security (United States)

Lei Tian, University of California, Berkeley (United States)

Sharene Young, U.S. Department of Homeland Security

(United States)

\section{Session Chairs}

1 Novel Systems I

Amit Ashok, College of Optical Sciences, The University of Arizona (United States) 
2 Novel Systems II

Amit Ashok, College of Optical Sciences, The University of Arizona (United States)

3 Reconstruction and Threat Detection Algorithms I

Joel A. Greenberg, Duke University (United States)

$4 \quad$ X-ray Sources and Detectors

Joel A. Greenberg, Duke University (United States)

5 Reconstruction and Threat Detection Algorithms II

Amit Ashok, College of Optical Sciences, The University of Arizona (United States) 